\title{
非妊娠時の腹腔鏡下頸管縫縮術後に健児を得た一例
}

\author{
富山県立中央病院 産婦人科 ${ }^{11}$ 、富山大学 産科婦人科 ${ }^{2)}$ \\ 山口彩華 ${ }^{1}$ 、谷村 悟 $^{1)}$ 、竹村京子 ${ }^{2)}$ 、今井 宗 ${ }^{1)}$ 、吉越信一 ${ }^{1)}$ 、南 里恵 ${ }^{1)}$ 、 \\ 飴谷由佳 ${ }^{1)}$ 、舟本 寛 ${ }^{1)}$
}

\section{Laparoscopic cervical cerclage; non-pregnancy; cesarean scar syndrome}

\author{
Ayaka Yamaguchi $^{1)}$, Satoshi Tanimura ${ }^{1)}$, Kyoko Takemura ${ }^{2)}$, Takashi Imai ${ }^{1)}$, \\ Shinichi Yoshikoshi ${ }^{1}$, Rie Minami ${ }^{1)}$, Yuka Ametani ${ }^{1)}$, Hiroshi Funamoto ${ }^{1)}$ \\ Department of Obstetrics and Gynecology, Toyama Central Prefectural Hospital ${ }^{1}$, \\ Department of Obstetrics and Gynecology, University of Toyama ${ }^{2}$
}

\begin{abstract}
Introduction: Prophylactic laparoscopic cervical cerclage is commonly performed in Western countries in women with prior failed transvaginal cervical cerclage or iatrogenic cervical shortening. However, this approach has not been reported in Japan. We report a case of laparoscopic cervical cerclage (LCC) in a non-pregnant woman.

Case: A 37-year-old woman who underwent a previous cesarean section underwent laparoscopic repair of a cesarean section scar (laparoscopic removal of scar tissue and resuturing) in $\mathrm{x}-2$ for infertility secondary to cesarean scar syndrome. Extensive scar tissue resection causes cervical shortening and might predispose to miscarriage and premature delivery. Our patient conceived naturally in $\mathrm{x}-1$; however, she developed rupture of membranes at week 17 and underwent a miscarriage. She once again conceived naturally 5 months later. She developed cervical shortening at week 13, and underwent transvaginal cervical cerclage at week 16. Premature rupture of membranes led to miscarriage at week 20. Following informed consent, we performed LCC during the non-pregnant state in $\mathrm{x}$. She conceived after ovulation induction in $x+1$ and was hospitalized for cervical shortening at week 25 . At week 31 , she underwent emergency cesarean section following a high rupture of membranes. Currently, the infant is 10 months old without any developmental issues.

Discussion: We report successful LCC during the non-pregnant state in a woman who delivered a preterm but otherwise healthy neonate. LCC during the non-pregnant state might be an effective strategy in women with failed transvaginal cervical cerclage during pregnancy.
\end{abstract}

Key words: laparoscopic cervical cerclage, non-pregnancy, cesarian scar syndrome

\section{【緒言】}

頸管縫縮術は日本のガイドラインでは妊娠 12 週 以降に経腟で行うことを推奨しているが、経腟以 外のアプローチ法に関する記載はない。海外で は非妊娠時にも行われており、経腟頸管縫縮術無 効例や医原性頸管短縮例に対しては、経腹アプロ ーチ（開腹または腹腔鏡）でも行われている2。
しかし、国内での非妊娠時の腹腔鏡下頸管縫縮術 の報告はない。今回妊娠中の経腟頸管縫縮術は無 効であったが、非妊娠時に腹腔鏡下頸管縫縮術を 行い健児を得た症例を経験したので報告する。

\section{【症例】}

37歳、 1 妊 1 産（41週で胎児機能不全のため帝 王切開) 
既往歴：X-2年帝王切開術後の不妊を主訴に受 診した。超音波検査や子宮ファイバースコープ、 カテーテル吸引により子宮内腔と帝王切開創部に 血液貯留を認めたため、帝王切開㓔痕症候群と診 断した ${ }^{3)}$ 。通常不妊治療で妊娠しなかったため帝 王切開瘏痕症候群に対して当科で腹腔鏡下帝王切 開瘏痕修復術を施行した。X-1年に自然妊娠した が、妊娠17週で破水し流産した。その 5 ヶ月後に も自然妊娠したが妊娠13週で頸管短縮を認め、妊 娠16週で経胵頸管縫縮術施行するも妊娠20週で胎 胞脱出し流産となった。帝王切開㓔痕修復術以前 に流早産はなかった。腹腔鏡下帝王切開瘢痕修復 術前後MRIを比較すると、術前（䁰管長 $30 \mathrm{~mm}$ ) に比べて術後（頸管長 $20 \mathrm{~mm}$ ）は頸管が短縮して いた（図 1 )。

現病歴：経臸頸管縫縮術が無効であったこと、 解剖学的に頸管が短縮していることの 2 点を認め たため、X年に患者の同意を得て非妊娠時に腹腔 鏡下頸管縫縮術を行った（当院倫理委員会承認済 み No.55-77)。

手術は全身麻酔+伝達麻酔（腹直筋鞘ブロック） 下で開始し、ダイヤモンド法に配置した 4 ポート で行った。膀胱子宮窩腹膜と広間膜前葉を切開・ 剥離し左右の子宮静脈、子宮動脈上行枝を血管の 走行がある程度視認できるまで露出させ、穿刺部 位を同定した（図 $2 \mathrm{~A} ） 。$ 縫縮にはテフロンテー プであるサンリッ子宮頸管縫縮用鈍針（シロッカ 一用：三立医科工業株式会社）を使用した。瘏痕 修復部と同レベルの子宮狭部で縫縮した。縫縮す るテフロンテープが腹腔内に露出していると感染 のリスクとなるため、当院独自の工夫として埋め 込みのための切開を子宮後壁側に入れた（図 2 B)。子宮頸管脇を背側から穿刺し、後壁のテフ ロンテープを吸収糸で埋包した（図 $2 \mathrm{CDE}) 。 ま$ た前壁の縫合糸結紮部（図 $2 \mathrm{~F}$ ）も膀胱子宮窩腹
膜を吸収糸で埋包した。手術時間150分、出血量 $13 \mathrm{~mL}$ 。術後、頸部から体部への移行部に結杽糸 が位置するのを超音波検査で確認し（図 3 )、頸 管長は40mmであった。

腹腔鏡下頸管縫縮術後、排卵誘発法で妊娠が成 立した。15週 2 日で頸管長 $28 \mathrm{~mm}$ （図 4 )、25週 で頸管短縮（頸管長 $18 \mathrm{~mm}$ ）を認めたため入院管 理とした（図 5 )。31週 2 日で高位破水したため、 緊急帝王切開で女児を婏出した (Apgar score 8/8、体重1372g、臍帯血ガス分析pH 7.390)。術中、 テフロンテープは頸管内左側壁に一部露出してい た。テープを引き抜くことが困難であったため、 頸管内に露出した糸と体部前壁の結紮部位のみを 切除した。経過良好で産後 5 日目に退院した。児 は生後10ケ月時点で発達異常は認めていない。

\section{【考察】}

妊娠中の経腟頸管縫縮術無効例に対して非妊娠 時に腹腔鏡下頸管縫縮術を行い健児を得た。

本症例では非妊娠時に頸管縫縮術を行った。頸 管縫縮術の施行時期に関しては、日本のガイドラ インでは妊娠12週のなるべく早期に行うと記載さ れており、妊娠中の記載しかない" ${ }^{1)}$ 。しかし、海 外のガイドラインでは非妊娠時、妊娠中のいずれ でも行うと記載されている ${ }^{2)}$ 。非妊娠時の手術で も妊娠率に差はなく、妊娠中の手術と比べて周産 期予後に差はないと報告されている 腹腔鏡下頸 管縫縮術を施行時期（非妊娠時vs 妊娠中）で比 較：妊娠 28 週以降での分婏率（71.4-83.3\% vs 70 $\%$ )、生児獲得率 (90-100％ vs 70-100\%) $\}^{4,5)}$ 。非 妊娠時に行う利点として、手術に起因する流産を 回避できること、妊娠子宮に比べて出血リスクが 低いこと、術野を確保しやすい、子宮マニュピレ ーターを使用できることが挙げられている。非妊 娠時に行う欠点として、妊娠しない場合や妊娠し
A

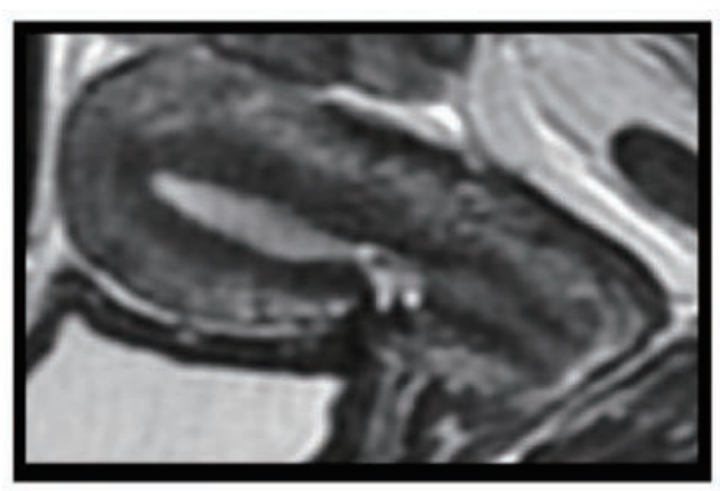

B

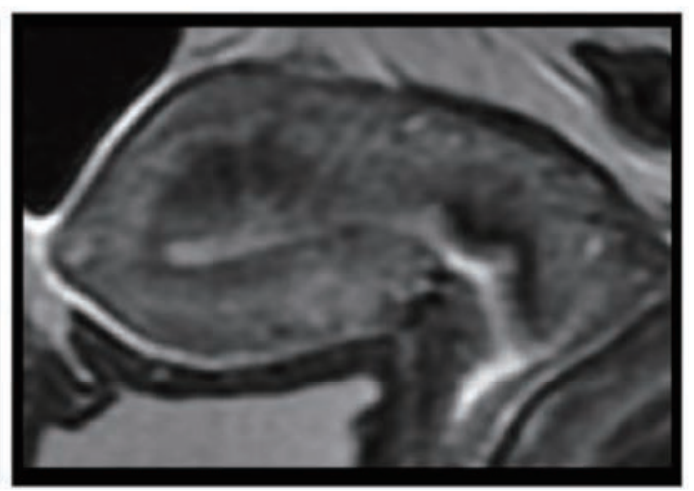

図 1 帝王切開痒痕修復術前後のMRI 

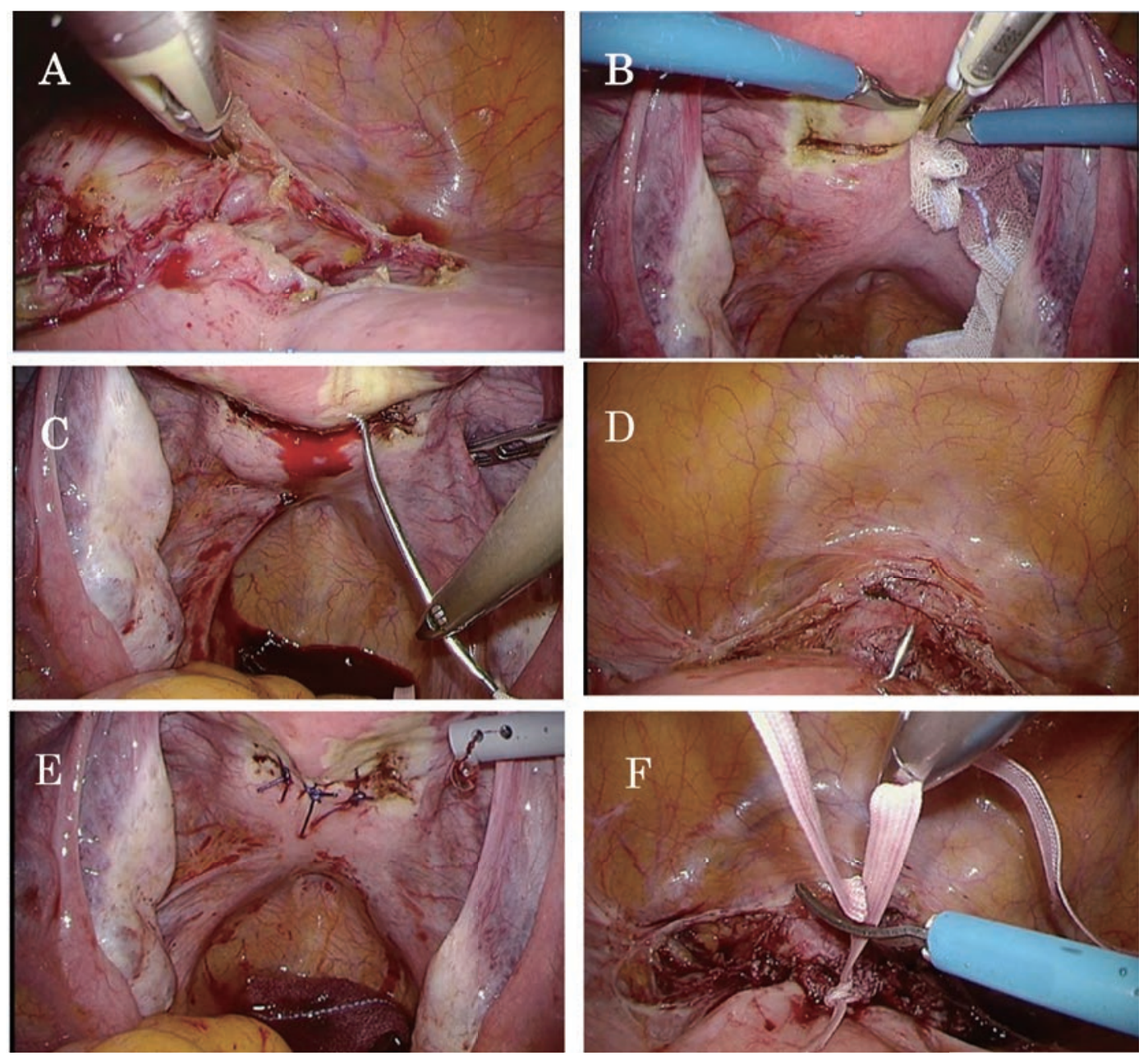

図2 腹腔鏡下頸管縫縮術の術中写真
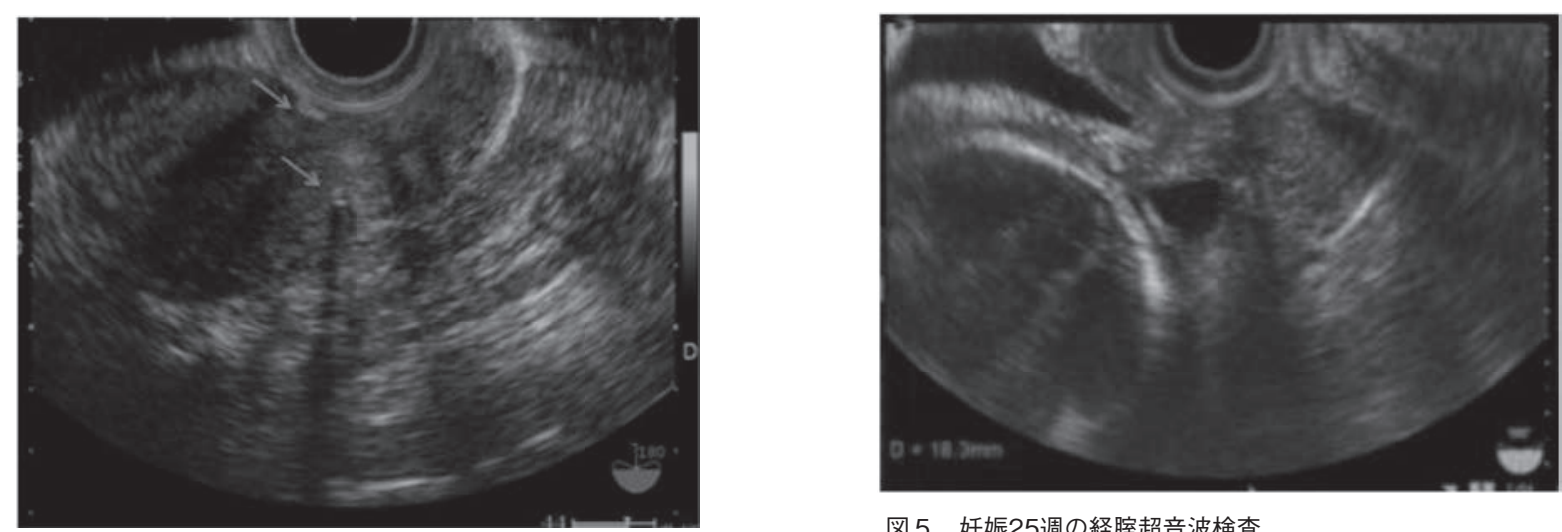

図 5 妊娠25週の経腟超音波検查

図３＼cjkstart腹腔鏡下頸管縫縮術後の経胵超音波検査

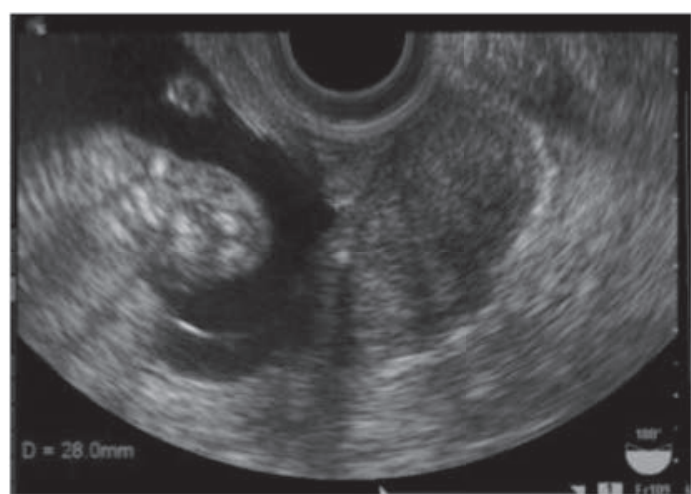

たが胎児死亡した場合の可能性を考慮しなければ ならない。妊娠しなければ縫縮糸は機能を果たさ ずにただの体内異物として残存することになる。 妊娠したが胎児死亡し流産手術が必要となった場 合には縫縮糸を抜糸しての流産手術や、抜糸が困 難な場合は腹式手術が必要となる可能性がある。 本症例についても上記の 2 点に関しての可能性を 説明し了承を得て施行した。また非吸収縫合糸が 腹腔内に露出することによる感染の危険性がある

図 4 妊娠15週の経腟超音波検査 
ことが挙げられている ${ }^{5,6)}$ 。子宮頸部摘出術後例で は、縫縮糸に起因したと推測される骨盤膿瘍も報 告されている7)。そのため私たちは露出を回避す るために子宮後壁に切開を入れて非吸収縫合糸を 埋め込む工夫をした。妊娠時に行う欠点としては、 胎児死亡した場合に、その原因の所在がはっきり しないことが挙げられる。手術操作によるものか、 手術に関係なく胎児因子などにより胎児死亡に至 ったのかはわからない。また、非妊娠時と比較し て手術難度は上昇する。

頸管縫縮術のアプローチ法として、経胵・経腹 （開腹、腹腔鏡）があり、本症例は当初経腟アプ ローチを施行したが無効であったため腹腔鏡アプ ローチを選択した。日本のガイドラインでは経腟 の頸管縫縮術の記載しかなく、経腹の記載はない ${ }^{11}$ 。 海外のガイドラインでは経腹頸管縫縮術の適応は 解剖学的に頸管が短縮あるいは経胵頸管縫縮術が 不成功例と明記されている ${ }^{2)}$ 。解剖学的頸管短縮 例には医原性の短縮もあり、子宮頸部円錐切除術 や広沉子宮頸部摘出術の既往、本症例のような帝 王切開㓔痕症候群修復術既往が含まれる。頸管短 縮による経腟手術手技困難な症例に対しても経腹 であれば手術可能であり、経腹頸管縫縮術の方が、 経腟頸管縫縮術より治療効果が大きいという報告 もある8)。

経腹頸管縫縮術の中でも腹腔鏡下頸管縫縮術は 開腹と比較して妊娠率に差はなく、術中流産や周 術期合併症（子宮穿孔, 骨盤内感染, 小腸損傷, 膀胱損傷, 子宮静脈損傷, 縫縮が不十分）の差は なかった ${ }^{9)}$ 。分娩結果は腹腔鏡下頸管縫縮術の方 が開腹より有意に良かった。\{中期流産率（3.70\% vs 7.79\%)、初期流産を除く新生児生存率 ( $96.14 \%$ vs $91.04 \%) 、 23-34$ 週で出生した確率（6.9\% vs 13.7\%)、34週以降で出生した確率（83.0\% vs $75.8 \%)\}^{9)}$ 。また腹腔鏡は開腹に比べ低侵襲であ り、拡大視野により子宮血管を同定できるため穿 刺の安全性が高いと考えられた。

帝王切開㓔痕修復術は菲薄化した痏痕部を腹腔 鏡下に切除し再縫合を行う手術であり、切除範囲 を広くした場合に頸管前壁が短縮しうる。本症例 では術前後のMRIで頸管前壁の術後短縮が確認で きた。2回の流産は頸管短縮を伴っており、修復 術が原因の一つと考えられるが、修復術後の妊娠 管理方法に関する報告はほぼなく、修復術をした 時点では頸管短縮による流産が起こることを事前 に予測することはできなかった。今後の症例蓄積 が必要である。
本症例は帝王切開㓔痕部の菲薄化修復術後であ り、修復後創部への緊張を減らすため幅のあるテ フロンテープを用いた。しかし、健児を得たもの の結果的にテープは頸管内の側壁に露出してお り、破水の原因となった可能性も否定できない。 帝王切開㓔痕修復術により菲薄化した筋層を修復 したが、疲痕化した組織は縫合しても脆弱であっ たため、テープが妊娠週数の進行と共に頸管内に 露出したと推測された。

海外では経腟頸管縫縮術無効例や解剖学的頸管 短縮例に対し経腹頸管縫縮術の適応があり、非妊 娠時にも行うとガイドライン上記載がある2)。し かし国内では非妊娠時に腹腔鏡下頸管縫縮術で健 児を得た報告はなかった。対象を限れば非妊娠時 に腹腔鏡で頸管縫縮術を行うことにメリットはあ る。一方、経腹アプローチでは非吸収糸の腹腔内 露出による感染リスクが指摘されていた。しかし、 私たちは子宮後壁漿膜下に埋包させることによ り、理論上そのリスクを軽減する手技を腹腔鏡で 行い得た。

非妊娠時の腹腔鏡下頸管縫縮術は海外では行わ れているが、国内での報告はない。その安全性や 適応、予後については更なる検討が必要である。

\section{【結論】}

妊娠中の経腟頸管縫縮術無効例に対し、非妊娠 時の腹腔鏡下頸管縫縮術後に健児を得た。有効性 の証明には症例の蓄積を要する。

本論文の一部は2016年の第56回日本産科婦人科 内視鏡学会学術講演会で前富山県立中央病院 竹 村京子らが発表した。

すべての著者は開示すべき利益相反はない。

\section{【参考文献】}

1) 日本産科婦人科学会/日本産婦人科医会：産婦人科診 療ガイドライン 産科編、2017; 147-151.

2) Clinical management guideline for ObstetricianGynecologists ACOG Practice Bulletin 2014; 142.

3 ) Satoshi Tanimura et al.: New diagnostic criteria and operative strategy for cesarian scar syndrome: Endoscopic repair for secondary infertility caused by cesarean scar defect. J Obstet Gynecol Res 2015; 41(9): 1363-1369.

4 ) N. B. Burger et al.: Effective of abdominal cerclage placed via laparotomy or laparoscopy: Systemetic 
review. J Minim Invasive Gynecol 2011; 18: 696-704.

5 ) Tulandi $\mathrm{T}$ et al.: Pre and post-conceptional abdominal cerclage by laparoscopy or laparotomy. J Minim Invasive Gynecol 2014; 21: 987.

6 ) D. Bolla et al.: Laparoscopic cerclage as a treatment optioin for cervical insufficiency. Geburtsh Frauenheilk 2015; 75: 833-838.

7 ) Okugawa K. et al: Pelvic abscess: A late complication of abdominal trachelectomy for cervical cancer. J Obstet Gynaecol Res. 2019; 45(2): 412-416.

8 ) Yuqing Chen et al:: Therapetic effect and safety of laparoscopic cervical cerclage for treatment of cervical insufficiency in first trimester or nonpregnant phase. Int J Clin Exp Med 2015; 8(5): 77107718.

9 ) Gaby N. et al: Systematic review of Transabdominal Cerclage Placed via laparoscopy for the Prevention of Preterm Birth. J Minim Invasive Gynecol 2018; 25: $277-286$.

投稿日: 2018年11月17日

採択日: 2019年 7 月17日 